\title{
FOREWORD TO FIFTH PRINTING
}

R. S. Kuykendall spent four decades of his life writing the history of Hawaii. He came to the Islands in 1922 as executive secretary of the newly formed Historical Commission of the Territory of Hawaii. The Commission planned, among other projects, to publish a large-scale history: a general narrative of a thousand pages or more, sufficiently documented to ensure "authoritativeness." Working to this mandate, Kuykendall brought to bear on his task everything he could muster in the way of personal and professional resources. He was well suited to the sort of pioneer labor that faced him. He had a great appetite and aptitude for spadework of an archival kind, locating, acquiring, and organizing collections of documents. His use of materials was marked by a quite outstanding scrupulosity with regard to matters of fact. Whatever industriousness and commonsensical perceptiveness could wring from often inadequate, often intransigent sources, Kuykendall set himself to extract.

Though the Historical Commission itself did not survive the Great Depression, Kuykendall, continuing his researches as a faculty member of the University of Hawaii, published the first volume of The Hawaiian Kingdom in 1938. Essentially this marked the advent of professional scholarly historiography in Hawaii. Kuykendall continued to devote most of his energies in middle and old age to a second and then a third volume. When he died in 1963, at age 78, Emeritus Professor of History and Honorary Doctor of Humane Letters of the University of Hawaii, he was working on the final chapter of the third and last volume, discussing the revolution that brought down the Hawaiian monarchy in 1893 . The completed trilogy became his monument.

Kuykendall's work for the Historical Commission was to be "official" as well as authoritative. This suited his temperament. He seems to have been well content to regard himself as a reliable chronicler rather than as an interpreter or reinterpreter of events. He never found it necessary to put much on paper about his own philosophy of history. Indeed we have to go to his private correspondence to find even so brief and unexceptionable a statement as this one: "It is the business of the historian to tell the truth, the whole truth, and nothing but the truth-to draw a faithful picture (a moving picture, if you please) of the past.... Until comparatively recent times, the exploits of kings, diplomatic intrigues, religious controversies, and wars were about the only things that historians wrote about. That, of course, gave a very one-sided, incomplete picture of human life. Nowadays, historians try to give a complete picture, with proper attention to all factors, including social, economic, and 
psychological conditions and developments. Hence it happens that kings, priests, diplomats, and battles have to share the scene with trade guilds, explorers, inventors, business men, farmers, educators, stevedores, and all the rest of us and our doings." If Kuykendall did not manage "completeness" (what historian ever does?), it is still the case that in the pages of The Hawaiian Kingdom the emerging major institutions of nineteenth-century Hawaii-schools and plantations and business houses, along with churches and royal courts-are presented for the first time in substantial array.

In another way Kuykendall was temperamentally well suited to the writing of "official" history. His view of his role as chronicler was equable and uninflected. He was content to see the past diligently documented and (in a sense) laid to rest. "As events recede into the past," he wrote in a letter composed only a few months after he began work in Hawaii, "we are able to see them in a truer perspective. And so, many controversies gradually lose the sharp edge of bitterness. Many actions which at the moment seemed due to malice are at length seen to have been the result of misunderstanding."

Be this as it may, in the years since Kuykendall died, and especially in the last few years, more and more people in Hawaii have begun to make pressing demands on the past. The 1970s, for instance, have seen a new birth of ethnic awareness in the Islands, and with this has come the quite legitimate insistence that the writing of history should take proper account of the lives of the hundreds of thousands of immigrants and their descendents who for so long made up the plantation workforce and later transformed the society and politics of the territory and the state. In the same way, an awareness is growing that Hawaii, for so much of its history marked by profound isolation, is now inescapably and irreversibly part of a world system of rapid population growth and movement, food production and consumption, and energy use. The major firms that dominated the plantation economy of the Islands under the Hawaiian kingdom are now multinational conglomerates, and they make their decisions about their Hawaii operations in a global context. The ocean that for so long in Hawaii's history was a buffer against the outside world is becoming the earth's last highly controverted frontier of economic exploitation-and military-strategic contest. These and any number of other urgent considerations impose a continuing need for the reassessment of the past in relation to the present and the future.

And yet all this by no means invalidates Kuykendall's work. On subjects concerning the establishment of the frame of government of the kingdom, and on Hawaii's early political and economic relations with the outside world, he remains authoritative. On a host of other topics he remains instructive. As a guide to sources his work is invaluable. He would never have claimed-modest man that he was-that his work was definitive. But certainly it was the best that had been done up to his time, and in many ways it remains the best. If The Hawaiian Kingdom is no longer sufficient to the needs of those who want to know about Hawaii's past, it is nonetheless still necessary. 
Kuykendall was by no means insensitive to the proposition that the passage of time brings about reorientations between present and past. With the best historians of his own day, he believed that each generation must reinterpret history for itself. As this process goes ahead in the Islands, however, The Hawaiian Kingdom goes on being consulted. Volume I has been reprinted in every decade since its publication, and it is a pleasure to see it being made available once again.

October 1976

Gavan Daws 
